\title{
Article
}

\section{Excavations and the afterlife of a professional football stadium, Peel Park, Accrington, Lancashire: towards an archaeology of football}

Peterson, Richard and Robinson, David Wayne

Available at http://clok.uclan.ac.uk/3449/

Peterson, Richard ORCID: 0000-0002-4185-1288 and Robinson, David Wayne ORCID: 0000-0002-0729-5011 (2012) Excavations and the afterlife of a professional football stadium, Peel Park, Accrington, Lancashire: towards an archaeology of football. World Archaeology, 44 (2). pp. 263-279. ISSN 00438243

It is advisable to refer to the publisher's version if you intend to cite from the work. http://dx.doi.org/10.1080/00438243.2012.669643

For more information about UCLan's research in this area go to http://www.uclan.ac.uk/researchgroups/ and search for <name of research Group>.

For information about Research generally at UCLan please go to http://www.uclan.ac.uk/research/

All outputs in CLoK are protected by Intellectual Property Rights law, including Copyright law. Copyright, IPR and Moral Rights for the works on this site are retained by the individual authors and/or other copyright owners. Terms and conditions for use of this material are defined in the policies page. 


\section{Social Memory and Ritual Performance}

Rick Peterson

Senior Lecturer in Archaeology

School of Investigative and Forensic Sciences

University of Central Lancashire

Preston PRI 2HE

UK

01772893495

rpeterson@uclan.ac.uk

Rick Peterson is senior lecturer and course leader for archaeology in the School of Forensic and Investigative Sciences, University of Central Lancashire. His current fieldwork focusses on the landscape setting and prehistoric occupation of caves and rock-shelters in the Forest of Bowland, Lancashire. His broader research interests include the British Neolithic, particularly pottery, small scale societies in prehistory and the Holocene archaeology of caves.

Subfields:

British Neolithic, Archaeologies of Memory, Archaeology of Natural Places

Suggested Referees:

Dr Andrew Jones, University of Southampton

Professor Richard Bradley, University of Reading 


\title{
Social Memory and Ritual Performance
}

\begin{abstract}
This paper is concerned with archaeological evidence for the mechanisms by which group memory is transmitted. Specifically, how do natural places such as caves and rock shelters retain their status as foci for ritual activity? It draws upon recent social and archaeological theory around embodied memory: in particular Connerton's (1989) division of memory claims into three kinds. These are: personal memory claims; cognitive memory claims; and habit-memory. It is argued that cognitive memory claims and habit-memory should be regarded as aspects of the same process of remembering, following Gell (1998) and Jones (2007) physical traces of past action are regarded as central to this act of memory. Three encounters with memory are analysed: managing memories; remembering a lesson learnt; and formal performance which reinforces group memories. It is argued that all three share some of the attributes of a ritual performance. An analysis of biographies of practice is proposed to draw out these links between small scale habit-memory and long term group memory.
\end{abstract}

KEY WORDS

Neolithic caves social memory embodiment ritual biographies of practice 


\section{INTRODUCTION}

This paper will address the question of how group memory is transmitted within societies. What are the effects of remembering collectively and how might we understand that process using archaeological evidence? These questions arose from fieldwork in small caves and rock-shelters at Goldsland Wood, Wenvoe in the Vale of Glamorgan (Aldhouse-Green and Peterson, 2007; Peterson and Aldhouse-Green in prep). Human remains occur over a long timescale at many prehistoric cave sites, particularly from the Neolithic onwards (Chamberlain, 1996; Dowd, 2008; Leach, 2008; Schulting, 2007). One of the Goldsland sites, George Rock Shelter, has fragmented human remains which have been radiocarbon dated to the beginning of the Neolithic period. Wolf Cave, around $500 \mathrm{~m}$ away, has similarly fragmented human remains but in this case with radiocarbon dates from the Early Bronze Age. At both sites there were also Neolithic pottery sherds, worked stone tools and debitage of Late Mesolithic to Late Neolithic date.

Therefore, at both George Rock Shelter and Wolf Cave there are strong indications of a set of depositional practices which begin in the Late Mesolithic and continue for a considerable period of time. This paper will examine how the transmission of memory within a group of people might work over a long timescale to develop this persistence of use.

\section{MEMORY AND EMBODIED EXPERIENCE}

These are questions which have received detailed consideration within archaeology over the last twenty years (for example: Borić, 2010; Bradley, 2002; Jones, 2007; Whittle et al., 2007a). This paper will review parts of that debate with reference to the particular problems of memory and natural places. One of the most profitable results of these works has been to shift discussions around remembering from a focus on discursive knowledge, where the only imaginable mechanism of transmission in prehistory is the oral poetic tradition, to embodied experience. An important influence here has been Paul Connerton's 1989 book How Societies Remember.

Connerton (1989, 2I-25) begins by analysing memory claims in general by dividing them into three broad classes. Firstly there are personal memory claims, memories which 'take as their object one's life history' (Connerton, 1989: 22). Secondly there are cognitive memory claims which relate to things one has met, learned of, or experienced in the past. A typical example would be abstract knowledge, such as the meaning of words. One of the identifying characteristics of this kind of memory claim for Connerton is that you do not need to remember when you learnt something to make use of it. Finally there is habit-memory; the ability to reproduce a physical performance, Connerton (1989: 22) uses the example of remembering how to ride a bicycle.

Jones (2007: 7-12) has reviewed different metaphors for how personal memory claims, Connerton's first class, might work. He rejects metaphors of memory as storage in which the brain is variously conceived as a storehouse, library or encyclopaedia of finite capacity. Jones (2007: 9) regards this vision of memory as problematic for two reasons. Firstly, it relies upon a model of memories as objective 'lumps' of data which are not interpreted in any way by the mind storing them. 
Secondly, and arising from that characterisation, the authenticity of knowledge is solely derived from the accuracy or otherwise of the mind's recall of these objective memories. Jones follows Clark (1997) in viewing memory as a process of pattern recreation which involves the mind, the body and the world. Clark views cognition as something which is created within the interaction of brain, body and world. For Jones memory is just this kind of knowledge; one that is contextually specific, experiential and embodied. This analysis of personal memory claims is extremely persuasive. The rest of this paper is primarily concerned with the slightly different case of the social transmission of memory but it will take as its starting point Jones' analysis of memory as a contextually specific, embodied and experiential phenomenon.

In analysing the second and third of Connerton's types of memory I want to suggest that cognitive memory claims and habit-memory are versions of a similar process of remembering. The example that Connerton (1989: 22) uses of a cognitive memory claim, knowing the meaning of words, is firmly within the realm of discursive knowledge. By contrast the example he gives of habit-memory, remembering how to ride a bicycle, is very clearly embodied knowledge. In both these cases it is not necessary to recall the point when the knowledge was learnt to make use of it (Connerton, 1989: 23). Cognitive memory claims and habit-memory are probably best regarded as names for either more discursive or more embodied versions of the same thing: remembering a lesson learnt.

In a recent paper Budden and Sofaer (2009) have used bodily practice to integrate what have traditionally been seen as opposed categories of discursive and nondiscursive knowledge. In existing studies, particularly in archaeological artefact analysis, they see a disjunction between 'top-down' discursive theory about symbolism and 'bottom up' embodied analysis of production processes (Budden and Sofaer, 2009: 204) Their examples focus on the transmission of knowledge about how to make pottery and how this serves to create the identity of 'potter' in the Hungarian Bronze Age. Budden and Sofaer analyse potting as an embodied performance. They follow Marcel Mauss in a vision of the châine opèratoire which includes the development not just of artefacts and knowledge but of the human body itself through repeated learning performances (Budden and Sofaer, 2009: 209).

Social memory, which is the main focus of this paper, is by definition all about communication. It cannot function without the transmission of information and therefore by default Connerton would classify it as habit or cognitive memory. In order to analyse the central role of material culture in memory, Jones (2007: 20-26) introduces the concept of indexing through a discussion of Gell's (1998) work on art. For Gell the artist and his work are inextricably entangled in time. All artworks draw on earlier work, without this link they would be unintelligible as art, and by doing so they connect the artist and the person experiencing the art to that past. By making the artwork the artist physically incorporates their bodily actions into the object, allowing them to be experienced in the future. It is a central part of Gell's (1998: 33, 68-72) discussion of how art works that the artist often consciously indexes their creative performance in the artwork. For example, early $20^{\text {th }}$ century art potters often sought to monumentalise the arcane craft skills needed in their work, making their pots 'theatres of technique' (de Waal 2003: 20-24). Pollard (200I: 3I7-8) takes this argument further when he defines aesthetic appreciation as 
the response of knowledgeable actors to these indices of creative performance. This gives us an embodied theory of aesthetics to set alongside Gell's anthropological theory of art.

It is important to note at this point that Gell (1998: 236-7) and Jones (2007: 22) are not claiming that objects experience memory, or that they act as an external store for human memories. Rather, objects which index past events in this way are part of the embodied, experiential world which allows memory to be created through the process of pattern recognition. From this perspective, scars and physical traces of past changes on artefacts, landscapes and natural features are evidence for past memories. By indexing the demonstrable passage of time they allowed the creation of memory. When we are considering social memory and the transmission of knowledge we are interested in a particular kind of memory creation: remembering a lesson learnt. These lessons become archaeologically visible when we can demonstrate the interaction between the kinds of physically indexing traces discussed by Gell and the social transmission of embodied skills.

Edmonds (1997: 105; 1999: 36-54) discusses examples of precisely this kind of interaction when people were learning to work stone among the debris of earlier knappers. He (Edmonds, 1997: 46-9) gives the example of the long-lived stone axe production sites of the English central Lakeland fells. At these sites trainee flintknappers would have knelt on a floor made of the flakes and discarded rough-outs of earlier lessons and learnt their skills surrounded by rock faces scarred by earlier fires and episodes of quarrying.

\section{Performing MEMORY}

There is more to social memory than the transmission of craft skills; however important these may be in the creation of the potters' or flint knappers' identity. This paper will analyse social memory by examining three different ways that bodies, places and objects might work together around memory and commemoration. These have been characterised as 'managing memories', 'remembering a lesson learnt' and 'formal performance'.

\section{Managing memories}

There are many archaeological sites where we have evidence for repeated ritualised action aimed at managing an immediate memory. An example of this would be the funerary rites associated with burial. The archaeological study of multi-stage funerary rites and the management of memory are well established, particularly for the Neolithic period. For instance, Fowler (2003) has drawn on the work of Battaglia and Küchler to interpret the exposure of human and animal bone. The decay and fragmentation acted to index the passage of time and, through that process, to manage memories of the deceased. Similarly, Reilly's (2003) model of multi-stage interment rites in Orcadian chambered cairns postulates both a ritual and a physical journey for the dead. Gradually decomposing bodies were moved through a staged series of resting places either within individual tombs or across a wider landscape cemetery. Leach (2008) has recently reviewed evidence for different kinds of managed transformation in the Neolithic human remains recovered from a group of caves in North Yorkshire. Detailed osteological study has demonstrated that, within 
a wider tradition of Neolithic cave burial, individuals with different life histories were treated in different ways after death.

In the examples given above the process of managing the physical and social transformation of the dead has been analysed by archaeologists in some detail. I would suggest that while processes are relatively well understood the visceral and emotional damage of grief and loss has often been omitted. The study of emotion in archaeology has been discussed in an influential paper by Tarlow (2000). She takes an experiential perspective to try and move beyond the position that emotions are either entirely culturally constructed or purely biological. Certainly it would be rash to assume that emotions are experienced in exactly the same way in all cultures around death, or even that it would be appropriate to categorise these emotions as equivalent to our concept of 'grief. However, given the compelling evidence for the need to manage transformations around death, some powerful emotional component to these practices needs to be acknowledged.

I want to make the claim that in studying the archaeology of funerals we are dealing with personal memory claims of Connerton's first class but with the twist that the archaeology probably represents strategies to manage a memory which is out of control and overly powerful. At times of great personal grief, at least in the modern West, Jones' (2007: 12) 'pattern re-creation' is both inescapable and horribly disabling. When everything recalls the dead person to mind then the physical indices of change, principally bodies and artefacts, are what need to be structured and normalised.

Battaglia (1992: 7-13) provides a very relevant ethnographic analogy for the mourning process as an extended performance which has the specific aim of managing the memory of the corpse. Among the Sabarl of the islands of southeastern New Guinea, a protracted and structured set of performances over a period of years resolve the social and emotional implications of the absence of the deceased. The Sabarl perceive death as a problem of interrupted obligations and therefore their mourning rituals involve highly theatrical and structured exchanges of different classes of objects. However, the end result of these rites, although they have the ostensible aim of forgetting the dead individual, is to create an emptiness: a physical space which remains associated with these particular performances. I would see this as an example of using performance to manage the transition from the raw grief of fractured social relations to a commemorative place which indexes a 'completed' and therefore more socially palatable memory.

Weiss (1997: 168-9) presents an example of similar processes of managed forgetting through a structured series of performances among the Haya of western Tanzania. In this case the 'completed' memory is indexed by portable mourning cloths worn by surviving descendants of the dead. I want to suggest a model for funerary ritual as an emotionally driven performance which works to manage that painful and dangerous direct personal memory of the deceased. Over time these embodied performative funerary rituals, such as the ethnographic examples discussed above, allow a more socially integrated memory of the dead to be indexed by a place, monument or artefact. 
At Goldsland Wood the archaeological evidence of this performance also seems to take the form of exposure burial. At George Rock Shelter there are the remains of seven individuals, probably all dating to the early part of the Neolithic.

Osteoarchaeological analysis of the skeletal material gives some indications of the rituals around death (Williams, 2008 and Figure I). The picture is somewhat complicated by later disturbance, particularly the pit containing context 1009. However, the primary rite seems to have been either exposure on the surface or shallow burial of single bodies on repeated occasions. This took place close to the rock wall at the back of the rock shelter, with the bodies parallel to the rock-face. Each successive burial disturbed the previously deposited remains, creating a fragmentary and collective mass from a series of burial events.

There are obvious parallels with well documented successive interment traditions at Cotswold-Severn chambered cairns such as Hazelton North (Saville, 1990: 250-2) and Wayland's Smithy I (Whittle et al., 2007b: I I 2-4). Parallels for the successive interment rite at Goldsland also comes from other Welsh caves sites, notably Little Hoyle, Tenby (Aldhouse-Green et al, 1996: 446) where the practice seems to date to around 3600 calBC.

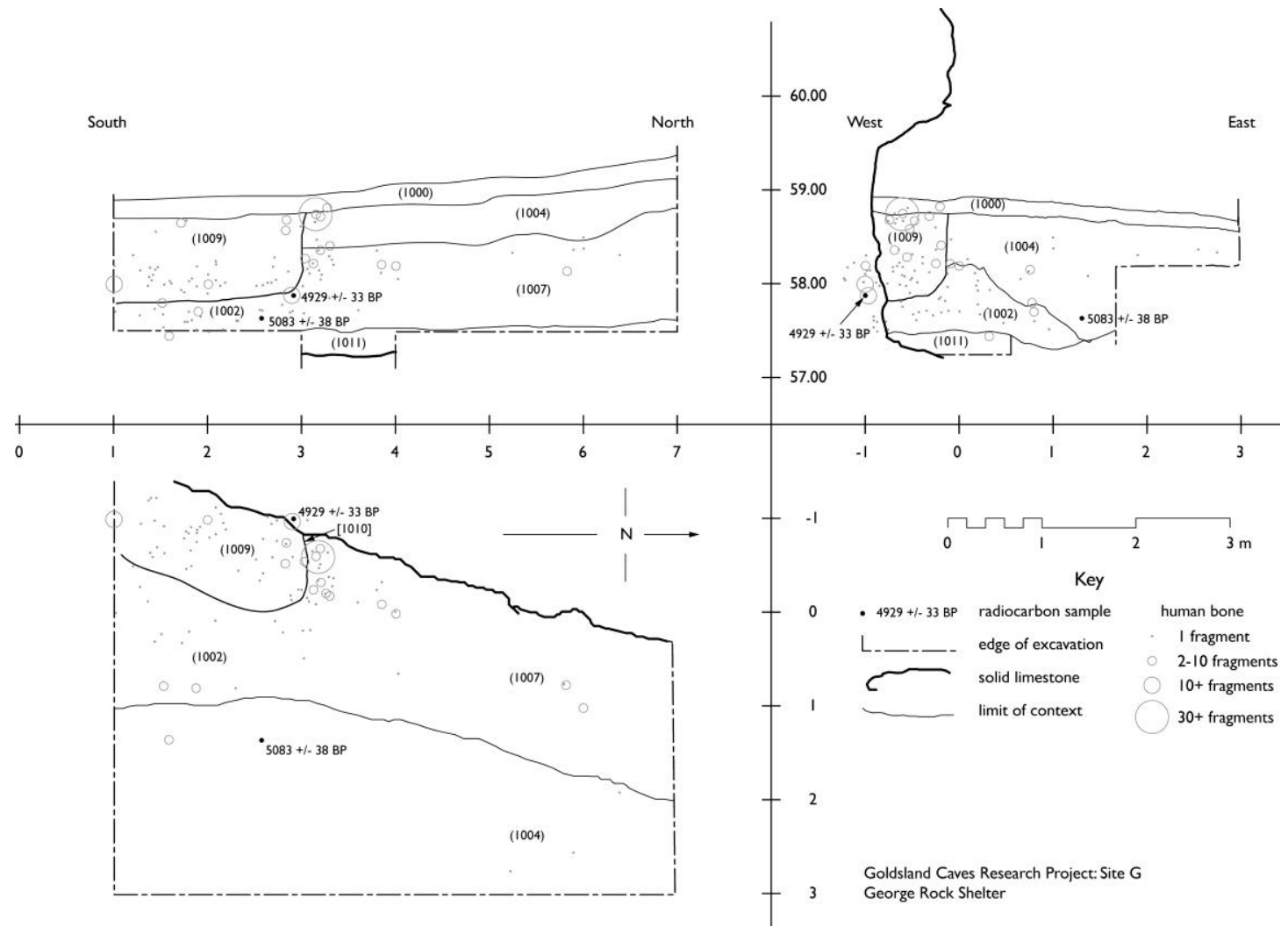

Figure I: One plan and two cross-sectional views of human bone deposition and associated radiocarbon dates at George Rock Shelter through the build-up of scree layers within the site. Bone distributions after Williams (2008: appendix I.I); radiocarbon samples dated by the Oxford Radiocarbon Accelerator Unit: $5083 \pm 38$ Cal BP (OxA-X-2424-44); $4929 \pm 33$ Cal BP (OxA-20968).

The rock-shelter deposits are a series of screes which formed relatively slowly, so we should envisage the human bone being placed on the surface of the scree then 
gradually being dispersed and incorporated into the matrix. The depth of deposit (Figure I) indicates a lengthy timespan for these seven rituals and, in view of the Early Bronze Age date from nearby Wolf Cave, we should remember that George Rock Shelter is likely to have been just one of a number of similar local sites which index this kind of performance. Interestingly, one of the George Rock Shelter screes (context 1002/1007) was actively forming granular tufa during the period of the funerary activity. The association between tufa deposits and human remains has been noted by Leach (2008: 5I-2) at Cave Ha 3 and Thaw Head Cave in Yorkshire. She interpreted this as deliberately drawing on the petrifying power of the environment for specific burials which were not subject to 'normal' fragmentation over time, but were intended to remain whole. At George Rock Shelter, by contrast, we appear to have successive interment and fragmentation within a tufa forming environment. Leach (2008: 5I) cites other examples of ritual associations with tufa in prehistory and it may be that the tufa-producing screes were selected for their properties of whiteness, petrification and transformation.

At Goldsland the repeated act of successive interment over a long period of time indicates the power of embodied performance. Here a rite which helped manage the physical and social dislocations and transformations of death seems to have had the effect of marking out a particular place as memorialising this rite. Decaying flesh and scattered bone served to index George Rock Shelter and memorialise this process.

\section{Remembering a lesson learnt}

I next want to discuss examples of social memory that are less obviously associated with formal ritual practice. These are the repeated actions which arise from and inculcate bodily memory in learning and practicing life skills. As discussed above, this links together the unconscious habit-memory discussed by Connerton (1989: 22) with the importance of the indexing of the past identified by Jones (2007: 21 )

Learning a skill involves experiencing the embodied performance needed to carry out a particular task alongside the physical traces of the result of that performance. To use a sporting example, a cricketer hitting a ball needs to respond quickly and subconsciously to get feet, body, hands and eyes working in particular ways to execute a shot. If it is a good shot then the middle of the bat will hit the ball and a whole variety of sensual clues will tell the cricketer this. The look, sound and feel of the impact need to be integrated with the memory of the bodily movements that produced the shot. People learn to combine the action and the physical traces of the result by comparing their effort to other previous attempts. This has to be a social process, one where external guidance is given; very few skills can be learnt by individual trial and error.

Craft apprenticeships and sports coaching can provide many examples of the importance of indexing in developing this kind of habit-memory but one most familiar to archaeologists is being taught how to clean surfaces with a trowel. This skill involves learning to hold the blade at the correct angle to scrape the surface. There are requirements of bodily posture to achieve this: archaeologists hold the trowel handle close to the tang manipulating the blade to give a good compromise between control and power. Interestingly, this small piece of embodied knowledge is now indexed by the tang guard on the new plastic-handled 'archaeology' version of the WHS four inch trowel (Figure 2). Novice trowellers are instructed to adopt a stance 
that puts the weight of the upper body over the point of the trowel. At some sites the preferred position has been to balance on the balls of the feet, at others kneeling has been permitted, but on every teaching excavation I have observed sitting or reclining trainees have been corrected.

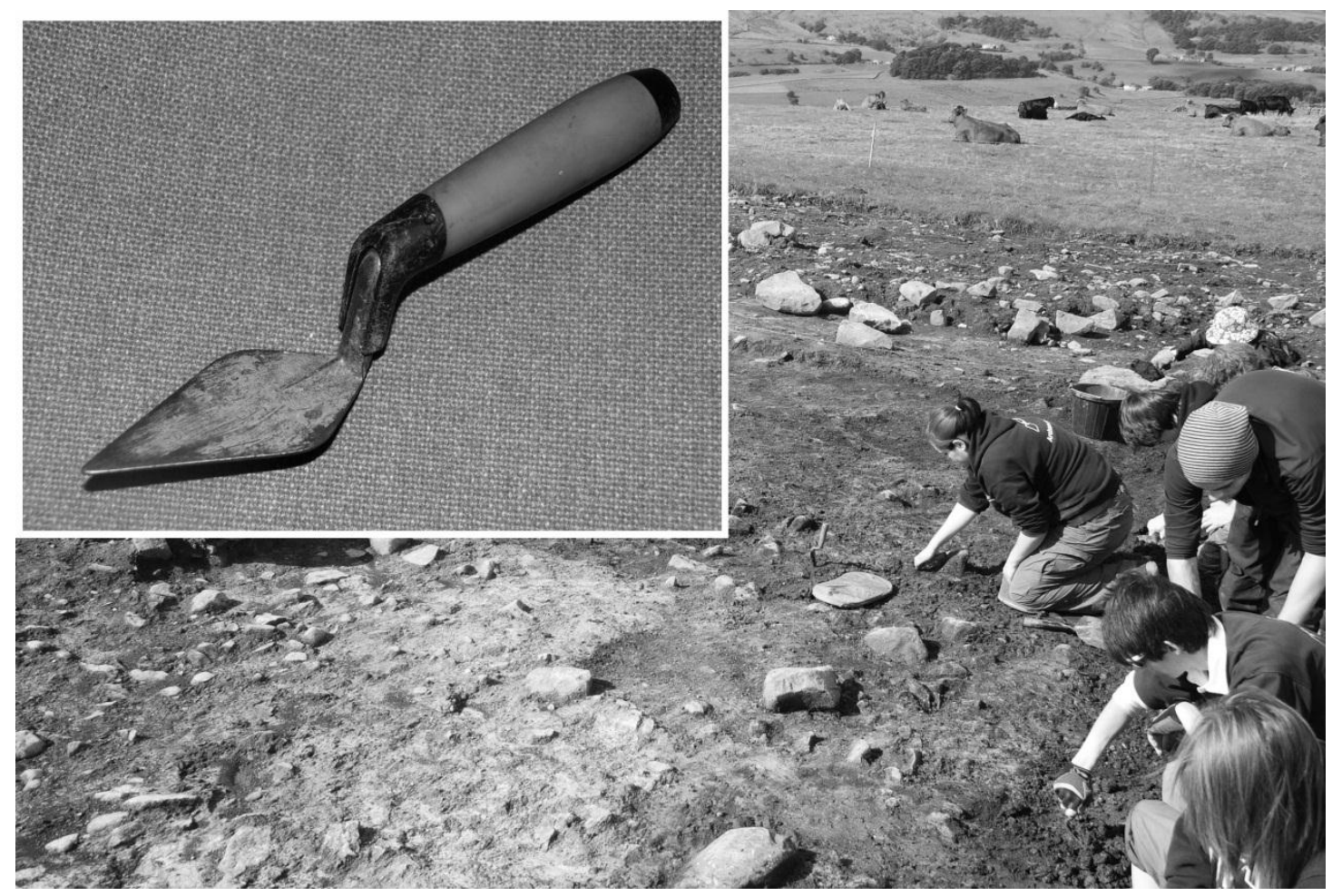

Figure 2: University of Central Lancashire students cleaning a surface during the excavation of the Moseley Heights ring cairn, near Burnley, Lancashire and (inset) the plastic-handled Spear and Jackson WHS four inch 'archaeology' trowel, showing the tang guard.

Michel Foucault (1979) analyses many similar processes of learning bodily skills, his interest is how objects and bodies entangle to produce the properly 'disciplined' body. However, in the case of his analysis of de la Salle's eighteenth century programme for teaching handwriting (1979: 152) there is explicit consideration of the interaction between bodily posture and the production of the external artefact, in this case a clearly written page. The descriptions of trowelling techniques given above and printed in archaeological manuals (for example, Atkinson, 1946: 38-9 and Webster, 1963: 92) are similar examples of the integration of the social response to the embodied performance and the indexing effect of the artefact being produced. Feedback on how the trainee is doing comes from both the person instructing and from the appearance of the completed cleaned surface they are producing. The teacher, tool, body and surface entangle to incorporate the habitual knowledge of how to repeat this process into our memories.

Trowelling a surface becomes something we can do without needing to remember how and when we were taught to do it and falls into Connerton's habit-memory class. However, and to slightly contradict Connerton, while you do not need to remember where and how you learnt to trowel in order to clean a surface successfully, everyone can always recall this event. The process of learning in this instance is so 
fundamental to an archaeologist's identity it becomes a sedimented part of their personal history. Along with the trowelled surface, they have created the kind of body that knows how to trowel.

To return to the example discussed earlier of learning to knap flint in prehistory, Edmonds (1999: 38) describes a locale at Ramsey, Cambridgeshire with a flint scatter of cores, narrow flakes and blades. Detailed analysis of the makeup of the assemblage leads Edmonds to the conclusion that both highly skilled and less skilled flintworkers were working together. Similar assemblages which may be characteristic of people learning to knap flint have also been reviewed by Finlay (1997: 207-9) for the Mesolithic and Upper Palaeolithic. Ramsey seems to be a place which was about production, in the sense that completed artefacts were removed from the site for use elsewhere. It was also a place where the embodied skills and indexing clues of learning to knap flint were tied to a particular place and time, particularly if Edmonds' suggestion of seasonality is accepted.

George Rock Shelter does not demonstrate the degree of evidence for flint knapping lessons identified at the sites above. However, the concentration of flintworking at particular times is strongly suggested. The distribution of worked stone debitage (Figure 3) shows a concentration of flint knapping within particular horizons. These seem to be coincident with the beginning and end of the formation of the tufa rich scree 1002/1007. The typology of the stone tools from the site reinforces this impression. The lithics include distinctively Late Mesolithic pieces such as narrowblade microliths. These clearly pre-date the earliest dated human remains on the site. There are also diagnostically Late Neolithic pieces such as a denticulated knife. The suggestion is that the majority of flint working and flint deposition at the site belong to distinct episodes which either pre-date or mark the end of the burial rituals. Some caution is necessary here as there are some Early Neolithic lithics, including a leaf-shaped arrowhead, residual in the later disturbance context 1009. However, the 'layered' distribution of lithics contrasts with the much more generalised pattern seen with Neolithic pottery sherds from the site.

Therefore, lithic production and deposition at George Rock Shelter was an embodied performance memorialised by a range of indices which served to link it to a specific time and place. A locale which people repeatedly visit, perhaps at particular times of the year, becomes a place where formal performances are going on which transform people's lives and capabilities. At which point learning and habit memory begin to take on many of the attributes of a formal commemorative ritual similar to those discussed by Connerton (1989: 4I-53). 


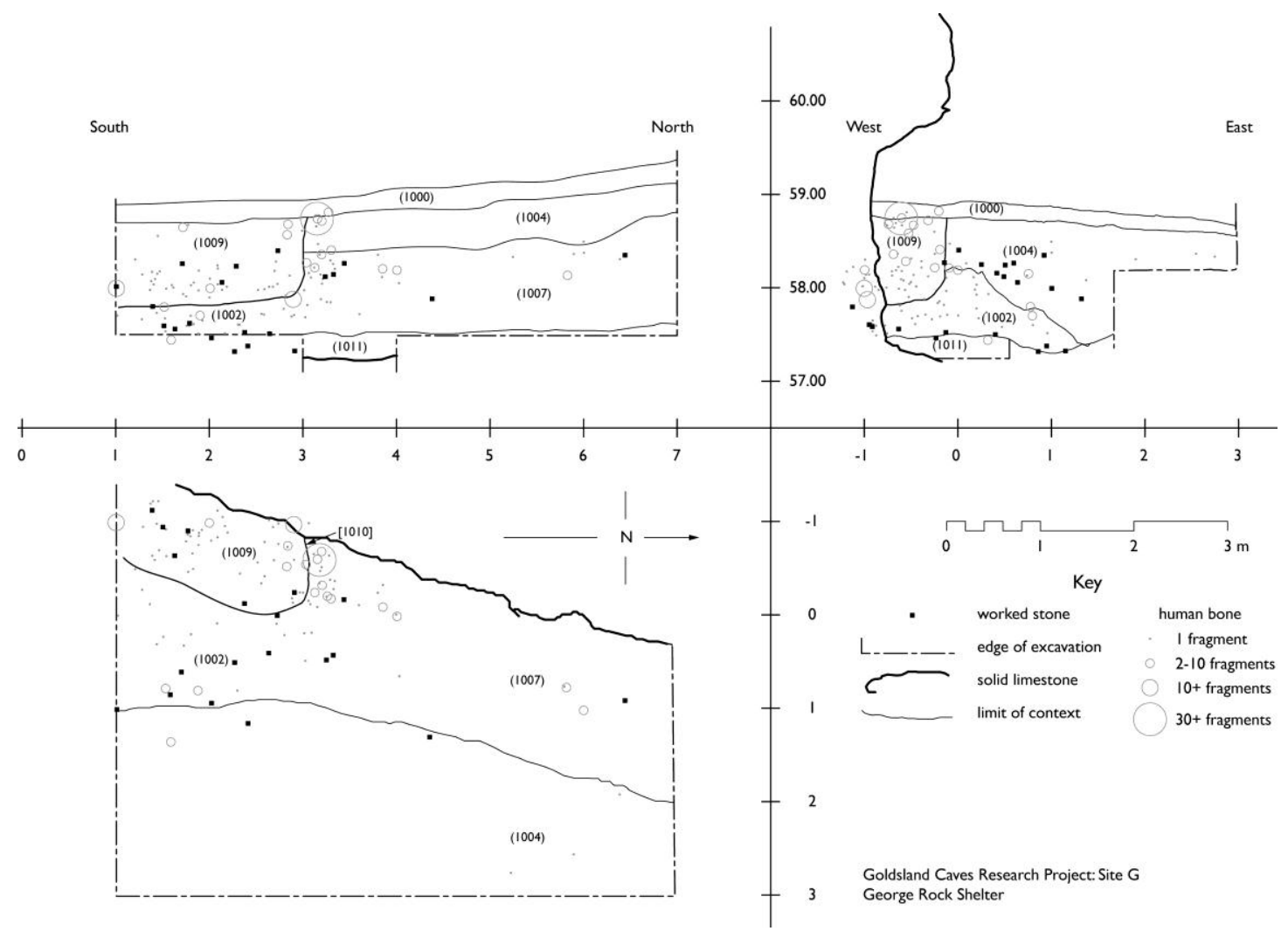

Figure 3: one plan and two cross-sectional views of George Rock Shelter showing the distribution of worked stone debitage through the scree layers.

\section{Formal performance}

This is the last of the three interactions between bodies, places and artefacts this paper will examine. Connerton (1989: 4I-7I) described at length the role of formal performance in encoding and reinforcing the ritual commemoration of semimythologized events or people. In general terms this takes the form of a bodily performance, or performances, which are specific to a place and a calendrically cyclical time. The formal ritual often incorporates both archaic language, repetition of gestures or impersonation of the people being commemorated.

According to Connerton (1989: 52-53), previous analyses of ritual had focussed on decoding or 'translating' content and symbolism rather than analysing form.

Connerton sees this as unhelpful in understanding what is specifically effective about commemorative ritual. There are obvious benefits to an archaeological study in focussing on the embodied, performative and experiential form of a ritual, rather than the symbolic discursive analysis of the myths and legends being commemorated. However, for Connerton, this is more than a matter of methodological convenience: a ritual does not represent a myth in another medium. Rather, the embodied performance of ritual only works on its own terms 'certain things can only be expressed in ritual' (Connerton, 1989: 54).

Connerton's point is that myth is flexible in its interpretation and presentation whereas the performative nature of the gesture and language of ritual encourages inflexibility and conservatism. He gives the example of the Christian liturgy (Connerton, 1989: 70), substantially unchanged throughout the history of the 
Western church, in which a series of bodily performances index specific past events and re-present them, literally make them happen in the present, around a particular location, the altar.

From the perspective of this paper the important point to analyse is how this embodied performance is indexed in places and artefacts. How is that degree of fixed calendrical repetition generated over long time periods? This indexing can take place just as effectively in caves and natural places as in built architecture. AldhouseGreen (2000: 243-5) made such a case for the Early Upper Palaeolithic activity at Goat's Hole Cave, Paviland where continuity of use was suggested for the period between 29000 and $21000{ }^{14} \mathrm{C}$ BP. Although this may seem an extremely long period, Goat's Hole Cave is part of the wider European Gravettian tradition. Gravettian burial practice remained remarkably constant over a similar timespan. The Paviland burial itself probably dates to around $29000{ }^{14} \mathrm{C} \mathrm{BP}$ (Jacobi and Higham 2008) with the latest burial at Sungir, Russia dated between 22500 and $23400{ }^{14} \mathrm{C}$ BP (Pettitt and Bader, 2000: 270).

The archaeology of Paviland seems to represent episodic visits to the site which probably coincide with milder sub-stages in the deteriorating climatic conditions of Early Upper Palaeolithic South Wales (Aldhouse-Green, 2000: 228). Aldhouse-Green (2004: 245) interprets these visits as shamanic ritual performances, common to wider Gravettian hunter-gatherer society (following Clottes, 1999), which perpetuated the memory of the cave as a ritual focus for pilgrimage over this immensely long period of time.

Bradley (1998: 5-13) provides another example in his review of the Sámi ritual cycle and its associated seijdde shrines at natural features in the landscape. Continuity of place is an important feature of such rituals. This provides a clear mechanism for the persistence of sacred places over long timescales. In his example Bradley (1998: 6) stresses the importance of the phenomenological distinctiveness of the particular rock feature chosen for the siejdde. However, many rock formations can be described as distinctive; but not all of them become ritual foci. The site may be chosen for its distinctiveness yet it is remembered because of the continued formal performance of the commemorative rite.

The details of this ritual performance are brought out by Mulk (1996) in a study of Sámi communities around the Lule River in northern Sweden between 700 and I400 AD. In this area shrines are located at distinctive natural features within the landscape and contain either seijdde stones or wooden figures; both of which represent divine 'masters of the animals', central figures in the animistic Sámi religion (Mulk, 1996: 52). Shrines were particularly associated with the winter settlements of these mobile hunter-fisher communities: which were also the locations for most of the social interaction within the wider Sámi group and for trade with agricultural communities to the south (Mulk, 1996: 64).

Seijdde shrines are interpreted by Mulk (1996: 64) as sites for gift giving, including sacrifice, as part of a redistributive system to maintain the egalitarian nature of Sámi society. From around 700 AD increased fur trade with the south gave the potential for the personal accumulation of wealth and the disruption of the egalitarian order. Mulk (1996: 70) argues that as there is no trace of such a development a very 
efficient re-distributive system of gift exchange was in place. Mulk (1996: 70-2) draws parallels with the growth of the potlatch in $19^{\text {th }}$ century north-western coastal groups in America, where a similar external source of wealth needed to be normalised.

Archaeologically these rituals are represented by the suspension and deposition of coins, beads and other trade goods and by the sacrifice and group consumption of particular classes of animals. The 'potlatching' incorporates more and more diverse trade goods into this process. Performing this deposition indexed the rituals in the artefacts and landscape of the seijdde shrines (Mulk, 1996: 73). Connerton's (1989: 44-5) observation that formal ritual has a cyclical calendrical element helps to make sense of the consistent association of the shrines with winter settlements. In the case of the Sámi of the Lale River, these ritual performances not only maintained social equality but perpetuated the active use of these seijdde shrines down to the adoption of reindeer pastoralism in the $17^{\text {th }}$ century (Mulk, 1996: 76). Persistence of place arises from the ritual action, to quote Paul Connerton once again: ' $A$ ritual is not a journal or a memoir. Its master narrative is more than a story told and reflected on; it is cult enacted.' (Connerton, 1989: 70)

\section{Memory AND the ORIgINS Of RITUAL PeRformanCE}

This brief review has begun to suggest how different practices around memory and the management of memory can all share a similar form. Despite their diverse origins, all three of the practices I have considered develop the trappings of ritual formal performances and therefore are likely to involve the creation of embodied social memory. Conversely, it is also likely that even the most complex ritual will have its origins within small scale embodied practices reworked and elaborated over time.

We can suggest certain conditions which must be met for embodied social memory to be transmitted: first, sociality, more than one person must be involved; second, indexing transformations must take place, to artefacts, places or bodies; third, performance, the embodied action at the heart of the process; fourth, approbation, this is the feedback received from objects and 'knowledgeable actors'; fifth, calendrical repetition; and finally, the spatial repetition that serves to index the group memory to the site.

Wherever these conditions occur it is likely that practices and places will be memorialised. The Goldsland example has illustrated that different classes of artefact can become implicated in social memory at the same site. Although the objects vary the social practices all meet the criteria outlined above. This has led me to the view that a key point of analysis will be around biographies of these practices.

Object biographies have been a fruitful area of study in archaeology: 'making salient what otherwise might remain obscure' (Kopytoff, 1986: 67). Research in this tradition has followed two trajectories. One has been to study the role of the artefact as the active subject participating in a range of exchange transactions; this is particularly rewarding when historical or ethnographic accounts can be called upon (for example, Gosden and Marshall, 1999). Another has been to draw upon the physical traces that manufacture, use and deposition have left upon an artefact or 
class of artefacts (for example, Joy, 2009). One important contribution of Joy's work on object biography has been to demonstrate that it is not essential for a meaningful analysis to be able to recreate every stage of an object's life (Joy, 2009: 543-4). His focus on multiple, partial biographies and the drama of object lives leads to an emphasis on relational biographies which takes us beyond biographies that are bounded by the class of thing being studied. This leads us to the idea of the biography of practice.

From this perspective the connections through the possible life history of a single artefact or class of artefacts are less relevant than the embodied network of practices in which it is specifically entangled. The George Rock Shelter lithics are part of a network of people and things which allow the memory of this particular rock shelter to be created and perpetuated. However, these practices are not confined to worked stones: by the Early Neolithic they have shifted to the exposure burial of bodies. Different kinds of indices now created memory at the shelter. The continuity of social, performative, embodied and indexing practice allowed the focus of the site to shift back to lithic deposition in the Late Neolithic. Here we have the biography of one practice, embodied social memory, running through many different physical manifestations.

\section{ACKNOWLEDGEMENTS}

This paper is an amalgamation of one given in the Memories Can't Wait session organised by Adrian Chadwick and Catriona Gibson at the Theoretical Archaeology Group meeting in Bristol in December 2010 and one given in June 2010 to the Upland Caves Network conference in Manchester organised by Hannah O'Reagan. Thanks to Chad, Catriona and Hannah for organising such stimulating sessions and to all the other contributors for two thoroughly thought-provoking discussions. Various versions of the text have been read and commented on by Olaf Bayer, Vicki Cummings, Julia Roberts and Samantha Walsh; thanks are due to them for their valuable input.

\section{REFERENCES}

Aldhouse-Green, S. and Peterson, R. (2007) 'The Goldsland Caves Research Project: Excavations in 2007', Archaeology in Wales 47: 68-7I.

Aldhouse-Green, S., Pettitt, P. and Stringer, C. (1996) 'Holocene Humans at Pontnewydd and Cae Gronw caves', Antiquity 70: 444-7.

Aldhouse-Green, S. (editor) (2000) Paviland Cave and the Red Lady. Bristol: Western Academic and Specialist Press.

Atkinson, R. (1946) Field Archaeology. London: Methuen.

Battaglia, D. (1992) 'The body in the Gift: Memory and Forgetting in Sabarl Mortuary Exchange', American Ethnologist 19(I): 3-I8.

Borić, D. (2010) Archaeology and Memory. Oxford: Oxbow. 
Bradley, R. (1998) An Archaeology of Natural Places. London and New York: Routledge.

Bradley, R. (2002) The Past in Prehistoric Societies. London and New York: Routledge.

Budden, S. and Sofaer, J. (2009) 'Non-Discursive Knowledge and the Construction of Identity: Potters, Potting and Performance at the Bronze Age Tell of Százhalombatta, Hungary', Cambridge Archaeological Journal 19(2): 203-220.

Chamberlain, A. (1996) 'More Dating Evidence for Human Remains in British caves' Antiquity 70: 950-3.

Clark, A. (1997) Being There: Putting Brain Body and World Together Again. MIT Press: Cambridge, MA.

Clottes, J. (1999) 'Twenty Thousand Years of Palaeolithic Cave Art in Southern France'. In Coles, J., Bewley, R. and Mellars, P. (editors) World Prehistory: studies in memory of Grahame Clark. Proceedings of the British Academy 99: I6I-I79.

Connerton, P. (1989) How Societies Remember. Cambridge: Cambridge University Press.

de Waal, E. (2003) Twentieth Century Ceramics. London: Thames and Hudson.

Dowd, M. (2008) 'The Use of Caves for Funerary and Ritual Practices in Neolithic Ireland', Antiquity 82: 305-I7.

Edmonds, M. (1997) 'Taskscape, Technology and Tradition' Analecta Praehistorica Leidensia 29: 99-II0.

Edmonds, M. (1999) Ancestral Geographies of the Neolithic: Landscapes, Monuments and Memory. London and New York: Routledge.

Finlay, N. (1997) 'Kid Knapping: Children in Lithic Analysis'. In. Moore, J. and Scott, E. (editors). Invisible People and Processes: Writing Gender and Childhood into European Archaeology. London: Leicester University Press: 203-I2.

Foucault, M. (1979) Discipline and Punish: the Birth of the Prison. (Translator Alan Sheridan) Harmondsworth: Peregrine Books.

Fowler, C. (2003) 'Rates of (Ex)change: Decay and Growth, Memory and the Transformation of the Dead in Early Neolithic Southern Britain'. In Williams, H. (editor) Archaeologies of Remembrance: Death and Memory in Past Societies. New York: Kluwer Academic/Plenum Publishers: 45-63.

Gell, A. (1998) Art and Agency: an Anthropological Theory. Oxford: Clarendon.

Gosden, C. and Marshall, Y. (1999) 'The Cultural Biography of Objects', World Archaeology 3 I(2): 169-78. 
Jacobi, R. and Higham, T. (2008) 'The 'Red Lady'ages gracefully: new ultrafiltration AMS determinations from Paviland', Journal of Human Evolution 55(5): 898-907.

Jones, A. (2007) Memory and Material Culture. Cambridge: Cambridge University Press.

Joy, J. (2009) 'Reinvigorating Object Biography: Reproducing the Drama of Object Lives', World Archaeology 4I(4): 540-56.

Kopytoff, I. (1986) 'The Cultural Biography of Things: Commoditization as Process'. In Appadurai, A. (editor) The Social Life of Things. Cambridge: Cambridge University Press: 64-91.

Leach, S. (2008) 'Odd One Out? Earlier Neolithic Deposition of Human Remains in Caves and Rock Shelters in the Yorkshire Dales. In Murphy, E. (editor) Deviant Burial in the Archaeological Record. Oxford: Oxbow: 35-56.

Mulk, I-M. (1996) 'The Role of the Sámi in Fur Trading During the Late Iron Age and Nordic Medieval Period in the Light of the Sámi Sacrificial Sites in Lapland, Northern Sweden', Acta Borealia 13: 47-80.

Peterson, R. and Aldhouse-Green, S. In preparation. Excavations in the Goldsland Wood Caves 2005-07.

Pettitt, P. and Bader, N. (2000) 'Direct AMS Radiocarbon Dates for the Sungir Mid Upper Palaeolithic Burials', Antiquity 74: 269-70.

Pollard, J. (200I) 'The Aesthetics of Depositional Practice', World Archaeology 33(2): 315-33.

Reilly, S. (2003) 'Processing the Dead in Neolithic Orkney', Oxford Journal of Archaelogy 22(2): 133-54.

Saville, A. (1990) Hazleton North, Gloucestershire, 1979-82: The Excavation of a Neolithic Long Cairn of the Cotswold-Severn Group. London: English Heritage. Schulting, R. (2007) 'Non-Monumental Burial in Britain: a (Largely) Cavernous View. In: Larsson, L., Lüth, F., and Terberger, T. (editors), Non-Megalithic Mortuary Practices in the Baltic - New Methods and Research into the Development of Stone Age Society. Schwerin: Bericht der Römisch-Germanischen Kommission 88: 58I-603.

Tarlow, S. (2000) 'Emotion in Archaeology', Current Anthropology 4I (5): 7I 3-46.

Webster, G. (1963) Practical Archaeology: An Introduction to Archaeological Fieldwork and Excavation. London: A and C Black.

Weiss, B. (1997) 'Forgetting Your Dead: Alienable and Inalienable Objects in Northwest Tanzania', Anthropological Quarterly 70(4): 164-72. 
Whittle, A., Barclay, A., McFadyen, L., Benson, D. and Galer, D. (2007a). Place and Time: Building and Remembrance. In Benson, D. and Whittle, A. (editors) Building Memories: the Neolithic Cotswold Long Barrow at Ascott-Under-Wychwood, Oxfordshire. Oxford: Oxbow: 327-364.

Whittle, A., Bayliss, A. and Wysocki, M. (2007b). 'Once in a Lifetime: The Date of the Wayland's Smithy Long Barrow', Cambridge Archaeological Journal I7(I): I0321 .

Williams, G. (2008) 'What Types of Mortuary Practice are Represented in the Human Bone Assemblage of Goldsland Cave? A Report on Site G: Skeletal Analysis, Interpretation and Discussion'. Unpublished BSc Dissertation: School of Forensic and Investigative Sciences, University of Central Lancashire. 